\title{
Viral and Bacterial Pathogens in Bovine Respiratory Disease in Finland
}

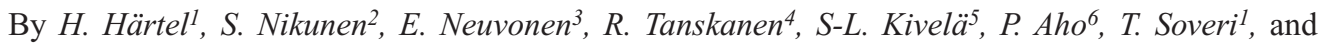 \\ H. Saloniemi ${ }^{1}$
}

${ }^{1}$ Department of Clinical Veterinary Sciences, and ${ }^{4}$ Department of Basic Veterinary Sciences, Faculty of Veterinary Medicine, University of Helsinki, and ${ }^{2} \mathrm{Järvi}$-Suomen Portti, ${ }^{3}$ Department of Virology and Epidemiology, Virology Unit, and ${ }^{5}$ Department of Bacteriology, and ${ }^{6}$ Kuopio Regional Laboratory, National Veterinary and Food Research Institute, Helsinki, Finland.

\begin{abstract}
Härtel H, Nikunen S, Neuvonen E, Tanskanen R, Kivelä S-L, Aho P, Soveri T, Saloniemi H: Viral and bacterial pathogens in bovine respiratory disease in Finland. Acta vet. scand. 45, 193-200. - Pathogens causing bovine respiratory tract disease in Finland were investigated. Eighteen cattle herds with bovine respiratory disease were included. Five diseased calves from each farm were chosen for closer examination and tracheobronchial lavage. Blood samples were taken from the calves at the time of the investigation and from 86 calves 3-4 weeks later. In addition, 6-10 blood samples from animals of different ages were collected from each herd, resulting in 169 samples. Serum samples were tested for antibodies to bovine parainfluenza virus-3 (PIV-3), bovine respiratory syncytial virus (BRSV), bovine coronavirus (BCV), bovine adenovirus-3 (BAV-3) and bovine adenovirus-7 (BAV-7). About one third of the samples were also tested for antibodies to bovine virus diarrhoea virus (BVDV) with negative results. Bacteria were cultured from lavage fluid and in vitro susceptibility to selected antimicrobials was tested. According to serological findings, PIV-3, BAV-7, BAV-3, BCV and BRSV are common pathogens in Finnish cattle with respiratory problems. A titre rise especially for BAV-7 and BAV-3, the dual growth of Mycoplasma dispar and Pasteurella multocida, were typical findings in diseased calves. Pasteurella sp. strains showed no resistance to tested antimicrobials. Mycoplasma bovis and Mannheimia haemolytica were not found.
\end{abstract}

bovine respiratory disease; calf; pneumonia; bacteria; virus; mycoplasma; tracheobronchial lavage; seroconversion.

\section{Introduction}

Bovine respiratory disease (BRD) is a major health problem of cattle worldwide. It inflicts considerable financial losses in beef herds (Moreno-Lopez 1990, Lekeaux 1995) and is the most common cause of mortality in dairy cattle (Wikse \& Baker 1996). It is also an important welfare problem of calves. The causation is multifactorial and the disease appears to be a result of the interaction of infectious micro-organisms and such predisposing factors as host defence, environment and stress (Roy 1990,
Wikse \& Baker 1996). Only a few reports exist on respiratory diseases of cattle in Finland ( $\mathrm{Sih}$ vonen \& Tuomi 1978, Tanskanen 1987, Rikula 2000). In addition, limited field studies have been published from other Nordic countries (Elvander 1996, Uttenthal et al. 1996, Norström et al. 2000, Larsen et al. 2001). Finland has a special situation, with freedom from certain aetiological agents. Infectious bovine rhinotracheitis (IBR, BHV-1), for instance, does not exist in Finland. Moreover, $M y$ - 
coplasma bovis has not been detected in Finnish cattle, and bovine virus diarrhoea (BVD) is very rare (Tanskanen 1987, Anon. 2000). Vaccines against respiratory disease are not used. Antimicrobials are generally not used for disease prevention and sick animals are mostly treated individually with antibiotics. However, the traditional farming system in Finland with small isolated cattle herds is changing. The dairy herds are enlarging gradually and calves of different ages are kept in group pens. In the new rearing system young calves at the age of 1-3 weeks originating from several dairy herds are transported to rearing units and reared in large groups. The aim of this study was to obtain basic knowledge of pathogens associated with bovine respiratory disease in Finland and to evaluate the occurrence of antimicrobial resistance in respiratory bacteria.

\section{Materials and methods}

\section{Sample collection}

This study was conducted from November 1998 to December 1999. Eighteen cattle herds situated in eastern, southern and western Finland were included. All herds had problems with bovine respiratory disease. Ten of the farms were rearing dairy-bred bull calves for beef, and 8 farms had dairy herds. The size of the beef-raising herds varied between 48 and 217 (mean 107) animals, and the dairy herds had 30-130 (mean 72) cows. Five diseased calves from each farm were chosen for closer examination, altogether 90 calves. A thorough clinical examination and tracheobronchial lavage were performed. The age of the diseased calves varied from 31 to 221 (mean 98) days and the weights were between 40 and 150 (mean 88) kg. All of the calves had abnormal sounds on auscultation of the respiratory tract, and most had either one or several of the following symptoms: fever $>39.5^{\circ} \mathrm{C}$, elevated respiratory rate $(>40 / \mathrm{min})$, cough or nasal dis- charge. One calf died 5 days after the examination and was autopsied. Blood samples for serological studies were taken from all calves at the beginning of the study, and second samples were taken from 86 calves 3-4 weeks later (paired serum samples). We also collected 6-10 blood samples from other animals of different ages on the farms to obtain more information about the serological situation of the whole herd. Some of the samples were taken from animals aged over 6 months to avoid the influence of maternal antibodies. The tracheobronchial lavage was taken with a special instrument made for collecting samples of the lower respiratory tract from calves (Bengtsson et al. 1998). The catheter was inserted nasally into the trachea. As lavage fluid, we used $30-40 \mathrm{ml}$ of phosphate-buffered saline (PBS, Dulbecco's phosphate-buffered saline, Gibco TM, Invitrogen Corporation, Paisley, Scotland, UK). The tracheobronchial fluid was immediately aspirated through the catheter and removed into test tubes with a glucose calf serum (GS) broth for mycoplasma and transport media for bacteria isolation (Portagerm multi-transport medium BioMerieux, Lyon, France). The quantity of the collected fluid varied from $2 \mathrm{ml}$ to over $20 \mathrm{ml}$.

\section{Detection of bacteria}

Tracheobronchial lavage samples from 85 calves in 18 herds were tested for bacterial growth. Samples were cultured on blood agar (tryptose-soya-agar containing $5 \%$ bovine blood) aerobically and anaerobically as well as on selective agar for Histophilus somni (formerly Haemophilus somnus) in a $\mathrm{CO}_{2}$-enhanced atmosphere. More specific identification was made with biochemical tests. The susceptibility of different Pasteurella sp. isolates for selected antimicrobials was tested. The antimicrobials used were ampicillin, penicillin, trimethoprim-sulfamethoxazole, gentamicin, tetracycline and enrofloxacin or ciprofloxacin. 
The bacterial tests were performed according to the standard procedures of the National Veterinary and Food Research Institute in Helsinki. The mycoplasma samples were kept frozen at $70^{\circ} \mathrm{C}$ until cultured. The media, culturing and identification methods used have been described elsewhere (Tanskanen 1984). Species identification was based on growth characteristics and the selective use of an epi-immunofluoresence (IF) test; only antisera against $\mathrm{My}$ coplasma dispar 462/2, Mycoplasma bovirhinis PG 43 and M. bovis Donetta PG 45 were used.

\section{Detection of viral antibodies}

Altogether 345 serum samples from 259 different animals were serologically tested for viral antibodies. Ninety samples were collected from diseased calves, 86 samples were paired serum samples from the same calves and 169 samples were taken from other cattle in the same herd. From each farm, 7-8 samples were from calves and 5-8 samples were from animals aged over 6 months. The serum samples were frozen at $-20^{\circ} \mathrm{C}$. They were tested for antibodies to bovine parainfluenza virus-3 (PIV-3), bovine respiratory syncytial virus (BRSV), bovine coronavirus (BCV), bovine adenovirus-3 (BAV3 ) and bovine adenovirus-7 (BAV-7). In addition, 123 samples from 94 animals were tested for antibodies to bovine virus diarrhoea virus (BVDV). An ELISA test was used for antibodies to PIV-3, BRSV, BCV and BVDV. A virus neutralization test was used for BAV-3 and BAV-7. The ELISA kits (SVANOVA Biotech, Uppsala, Sweden) were used according to the manufacturer's instructions. If a fourfold increase occurred in antibody titre in the neutralization test or if the ELISA test was seronegative in the first sample and seropositive in the second sample, the calf was considered to have a rise in titre and to be recently infected with the relevant virus.

\section{Results}

Results of the antibodies to viruses are presented in Table 1. Antibodies to PIV-3 and BAV-7 were found in all 18 herds. Antibodies to

Table 1. Serological findings of 18 cattle herds with respiratory problems.

\begin{tabular}{|c|c|c|c|c|c|c|}
\hline & $\begin{array}{l}\text { No. calves } \\
\text { (herds) }\end{array}$ & PIV3 & $\mathrm{BCV}$ & BRSV & BAV3 & BAV7 \\
\hline No. of herds positive & 18 & 18 & 16 & 12 & 15 & 18 \\
\hline Percentage of positive herds & 100 & 100 & 89 & 67 & 83 & 100 \\
\hline $\begin{array}{l}\text { No. of diseased } \\
\text { calves, }{ }^{1} \text { first sampling }\end{array}$ & $90(18)$ & $\begin{array}{l}66(18) \\
73 \%{ }^{2}\end{array}$ & $\begin{array}{l}35(15) \\
38 \%\end{array}$ & $\begin{array}{l}8(6) \\
9 \%\end{array}$ & $\begin{array}{l}46(13) \\
51 \%\end{array}$ & $\begin{array}{l}65(17) \\
72 \%\end{array}$ \\
\hline $\begin{array}{l}\text { No. of diseased calves, }{ }^{1} \\
\text { second sampling }\end{array}$ & $86(18)$ & $\begin{array}{l}58(17) \\
67 \%\end{array}$ & $\begin{array}{l}30(15) \\
35 \%\end{array}$ & $\begin{array}{l}5(5) \\
6 \%\end{array}$ & $\begin{array}{l}44(11) \\
51 \%\end{array}$ & $\begin{array}{l}72(17) \\
84 \%\end{array}$ \\
\hline No. of other animals ${ }^{1}$ & $169(18)$ & $\begin{array}{c}150(18) \\
89 \%\end{array}$ & $\begin{array}{l}57(14) \\
34 \%\end{array}$ & $\begin{array}{l}18(9) \\
11 \%\end{array}$ & $\begin{array}{c}107(15) \\
63 \%\end{array}$ & $\begin{array}{c}143(18) \\
85 \%\end{array}$ \\
\hline Rise in titre ${ }^{1}$ & $86(18)$ & $\begin{array}{l}3(2) \\
3.5 \%\end{array}$ & $\begin{array}{l}4(3) \\
4.7 \%\end{array}$ & $\begin{array}{l}0(0) \\
0 \%\end{array}$ & $\begin{array}{l}11(5) \\
12.8 \%\end{array}$ & $\begin{array}{l}20(10) \\
23.3 \%\end{array}$ \\
\hline Decrease in titre ${ }^{1}$ & $86(18)$ & $\begin{array}{r}9(7) \\
10.5 \%\end{array}$ & $\begin{array}{l}8(6) \\
9.3 \%\end{array}$ & $\begin{array}{l}3(2) \\
3.5 \%\end{array}$ & $\begin{array}{l}23(10) \\
26.7 \%\end{array}$ & $\begin{array}{l}20(8) \\
23.3 \%\end{array}$ \\
\hline
\end{tabular}

\footnotetext{
${ }^{1}$ Number of herds in parentheses. ${ }^{2}$ Percentage of calves
} 
$\mathrm{BCV}$ and BAV-3 were discovered in $16 / 18$ $(89 \%)$ and from 15/18 (83\%) herds, respectively. Antibodies to BRSV were found in 12/18 herds $(67 \%)$ and in all dairy herds. Antibodies to BVDV were detected in 0/7 herds. High levels of antibodies to BAV-7 in more than 2 samples in one herd were monitored on 14 farms (neutralization titre more than 1:512). In paired serum samples, a rise in titres occured in 33 of 86 calves (33\%) on 15 farms. Seroconversion for BAV-7, BAV-3, BCV and PIV-3 was seen on $10 / 18,5 / 18,3 / 18$ and $2 / 18$ farms, respectively. Titre rise for BAV-7 was most often seen on beef farms ( 8 herds) and titre rise for BAV-3 was most frequent on dairy farms (3 herds). Seroconversion to BRSV was not noted at any of the farms. Decreasing antibody titres (neutralization test) or a change from seropositive in the first sample to seronegative in the paired serum sample (ELISA test) was observed in 44 calves (51\%) on 15 farms.

All 18 herds and $93 \%$ of the calves (79/85) had mycoplasma findings. $M$. dispar was found in 17 herds (94\%) from 77 samples (91\%), and other mycoplasmas in 16 herds (89\%) from 52 samples (61\%). On 15 farms (83\%) and in 50 samples (59\%), M. dispar occurred together with other mycoplasmas. All classical colonies examined by the IF test proved to be M. bovirhinis. M. bovis was not detected. Other bacterial growth was found in 9 herds $(50 \%)$ in 18 samples $(21 \%$ of calves). The most common finding was Pasteurella sp., which was monitored in 14 samples ( $78 \%$ of positive samples) of 8 herds ( $44 \%$ of the herds and $17 \%$ of the calves). The Pasteurella sp. isolates were identified as $P$. multocida in 7 cases and P. multocida (indolenegative) in 6 cases. Most often Pasteurella sp. was the only finding, but in 2 cases it was found together with Fusobacterium necrophorum and once with Arcanobacterium pyogenes. F. necrophorum alone was found from 3 samples in 3 herds and $A$. pyogenes alone only from one calf in one herd. All calves with other bacteria in tracheobronchial fluid also had mycoplasmal growth. $M$. dispar and $P$. multocida together were isolated in 13 samples from 7 herds. Six calves of these 13 showed a seroconversion to viruses, 4 of them to BAV-3, one to BAV-7 and one to BCV and BAV-7 simultaneously. The post-mortem examination of the dead calf revealed signs of chronic fibrinopurulent bronchopneumonia. H. somni was cultured from the lungs, in contrast to $P$. multocida (indole-negative), which was found earlier in the tracheobronchial lavage fluid. All 14 Pasteurella sp. strains were susceptible in vitro to all antimicrobials tested (ampicillin, penicillin, trimethoprim-sulfamethoxazole, gentamicin, tetracycline, enrofloxacin or ciprofloxacin).

\section{Discussion}

According to the serological findings, PIV-3, BAV-7, BAV-3, BCV and even BRSV were common pathogens in Finnish cattle herds with respiratory problems. Finland is free from IBR and the occurrence of BVD is very rare (Anon. 2000). Both of these viruses have been considered to be important BRD-associated pathogens elsewhere (Wikse \& Baker 1996, Kapil \& Basaraba 1997, Potgier 1997, Obando et al. 1999). Our negative findings confirm that BVDV infection is not closely linked to occurrence of BRD in Finland. The different serotypes of bovine adenovirus are divided into 2 subgroups. Types 1-3 represent group A and types 4-9 group B (Mattson 1992). We chose to examine types 3 and 7. Our results agree with the findings of Sihvonen \& Tuomi (1978), who demonstrated that infections with BAV-1, -2 and -3 are common in cattle, at least in the southwestern part of Finland. To our knowledge the occurrence of BAV-7 has not been studied earlier in Finland. Here, seroconversion to BAV-7 was the most common, followed by seroconversion to BAV-3. Many of the older ani- 
mals, especially on the beef farms, had high titres of BAV-7, which may indicate that an acute infection caused by this virus has occured. Antibodies to PIV-3 were found on every farm examined, and almost $80 \%$ of all samples taken were positive for PIV-3. This is in agreement with the ubiquitous nature of the virus, with its world-wide distribution (Bryson 1990, Kapil \& Basaraba 1997). However, PIV-3 was not observed to be a causal factor. BCV has gained ground as a pathogen in respiratory disease complex recently (Storz et al. 1996, Lathrop et al. 2000, Storz et al. 2000). BCV may also be involved in respiratory disease in Finnish cattle. Antibodies to BRSV were found in $67 \%$ of the herds overall and in all dairy herds. However, BRSV did not appear to cause the disease in the calves studied. The situation might have changed after the respiratory disease outbreak in Finland in spring 2000; the causative agents of the epidemic were suggested to include BRSV and BCV (Rikula 2000). Although we detected antibodies to several viruses on each farm and even in high titres, we relatively seldom found seroconversion in the diseased calves. This is probably because of the young age of the calves and existing maternal antibodies which may suppress the calves ' own production of antibodies. This is in agreement with the results of a high number of decreasing antibody titres and with the conclusion of Virtala et al. (1996, 2000), who stated that young pneumonic calves often fail to seroconvert to agents present in respiratory tract because of suppressive maternal antibodies. Our failure to detect seroconversions might also be a consequence of missing the acute phase of the disease. Seroconversion to adenoviruses was seen in about half of the cases where also bacterial growth of M. dispar and P. multocida was noticed. There might have been some other predisposing factors than the viruses examined. Interpreting the importance of viral infection in this study is, however, problematic because we could not use any direct virus diagnostics from the tracheobronchial lavage and we did not have healthy calves or healthy herds as controls.

Mycoplasmas are considered to be one of the pathogens causing BRD. They are able to cause a mild respiratory disease by themselves, but more often they are isolated from pneumonic lungs together with other pathogens (Welsh 1993, Lauerman 1994, Walker 1995). The most common isolate from lavage fluid of diseased calves in our study was $M$. dispar. The predominant combination was $M$. dispar and P. multocida. In another study, a synergistic effect between Mycoplasma sp. and P. multocida was suggested (Virtala et al. 1996). We found no $M$. bovis which has not to date been isolated from Finnish cattle, and most likely it does not exist in Finland. However, many reports are available from other countries about the increasing prevalence of M. bovis (Brice 2000, Kusiluka 2000, Byrne 2001). The findings of $M$. dispar and Mycoplasma sp. did not differ much from previous reports in Finland. Tanskanen (1987) described a high prevalence of mycoplasma from nasal and transtracheal samples, and rapid spread of the infection in a population of young cattle. In our study, other bacteria were detected in only $21 \%$ of the tracheobronchial samples. Virtala et al. (1996) found in transtracheal wash samples (TTW) bacterial growth in $90 \%$ of the diseased calves and in $55 \%$ of the controls. $M$. haemolytica biotype A serotype 1 is considered to be the predominant and most pathogenic bacterium in pasteurellosis of feedlot units (Frank 1989, Mosier 1997). In our samples, we found no $M$. haemolytica.

P. multocida is another common pathogen reported to be involved in BRD, especially in dairy herds (Virtala et al. 1996, Mosier 1997). Some of our Pasteurella sp. strains differed in biochemical tests from the typical P. multocida by showing a negative reaction to indole. An 
important finding was that all Pasteurella isolates were susceptible to all of the antimicrobials typically used in the treatment of BRD in Finland. An explanation for the very few bacterial findings in spite of mycoplasmas may lie in the lavage technique and the relatively small fluid volume used. Alternatively, perhaps few pathogens were present in the tracheobronchial area at the time of the investigation. The postmortem finding of $H$. somni may indicate that we failed to detect some bacteria in the tracheobronchial area. However, the calf may have contracted the $H$. somni infection after the lavage and the P. multocida infection. Tegtmeier et al. (1999) described H. somni as a frequent finding in autopsied calves with respiratory disease in Denmark. H. somni has seldom been found in Finland, with only 10 reports in the last 10 years and only in connection with respiratory disease (Niskanen et al. 1999). Isolation of $A$. pyogenes and $F$. necrophorum without any other bacteria was considered to be a contamination or a coincidental finding. No connection to the poor prognosis of calves with $A$. pyogenes was seen, in contrast to Scholz et al. (1987) and Mosier (1997). The scant bacterial findings and low mortality in our study may also indicate that the severity of the disease was lower than in many other studies.

\section{Conclusions}

According to serological findings, BAV-7, PIV3, BAV-3, BCV and BRSV are common viruses in Finnish cattle herds suffering from respiratory disease. Seroconversion to BAV-7 and BAV-3 occurred most often. These results suggest an active role of adenoviruses, particularly BAV-7, in respiratory diseases in cattle in Finland. Antibodies to BRSV were detected mainly in older animals without signs of respiratory disease and no seroconversion. Tracheobronchial lavage revealed few pathogens other than mycoplasmas, which could be found in all herds in this study. The most common bacterial findings were P. multocida and M. dispar, suggesting their importance in respiratory problems. How these 2 pathogens interact together and with viral pathogens remains to be clarified. M. haemolytica and M. bovis were not found, and $H$. somni was only found in the lungs of the autopsied calf. New calf-rearing systems, where large groups of young calves are reared in close proximity, may increase respiratory problems considerably also in Finland. Larger studies which will enable more information to be gathered about respiratory diseases and the roles of different pathogens are therefore warranted.

\section{Acknowledgements}

The authors are grateful to Hannele Pentti for technical assistance, Marja-Liisa Tasanko for laboratory assistance and Professor Satu Pyörälä for sound advice. Thanks are also given to the veterinary colleagues who helped us to collect blood samples. We thank Dr. Björn Bengtsson from Sweden for kindly giving us the model of the instrument for tracheobronchial lavage. The practical study was supported by a scholarship from Hoechst Fennica, and the mycoplasma study by a scholarship from Pfizer Animal Health.

\section{References}

Anonymous: Contagious animal disease in 2000. National Veterinary and Food Research institute EELA, Annual report 2000, 29-30.

Bengtsson B, Franklin A, Gånheim C, Jacobsson S-O, Persson $M \&$ Viring $S$ : A simple field method for tracheo-bronchial lavage in calves. Proceedings of XX World Buiatrics Congress, Sydney, 6-10 July 1998, Vol. 2, 1127.

Brice N, Finlay D, Bryson DG, Henderson J, McConnell $W \&$ Ball HJ: Isolation of Mycoplasma bovis from cattle in Northern Ireland, 1993 to 1998. Vet. Rec. 2000, 146, 643-644.

Bryson DG: Parainfluenza-3 Virus in Cattle. In: Dinter $Z \&$ Morein $B$ (eds): Virus infections in Ruminants, Elsevier publishers, Amsterdam, 1990, 319-333.

Byrne WJ, McCormack R, Brice N, Egan J, Markey B $\&$ Ball HJ: Isolation of Mycoplasma bovis from 
bovine clinical samples in the Republic of Ireland. Vet. Rec. 2001, 148, 331-333.

Elvander M: Severe respiratory disease in dairy cows caused by infection with bovine respiratory syncytial virus. Vet. Rec. 1996, 138, 101-105.

Frank GH: Pasteurellosis of Cattle. In: Adlam $C \&$ Rutter JM (eds): Pasteurella and Pasteurellosis, Academic Press, London, 1989, 197-222.

Kapil $S$ \& Basaraba RJ: Infectious bovine rhinotracheitis, parainfluenza-3, and respiratory coronavirus. Bovine respiratory disease update. Vet. Clin. North Am. Food An. Pract. 1997, 13, 455469.

Kusiluka LJM, Ojeniyi B \& Friis NF: Increasing prevalence of Mycoplasma bovis in Danish cattle. Acta vet. Scand. 2000, 41, 139-146.

Larsen LE, Tegtmeier C\& Pedersen E: Bovine respiratory syncytial virus (BRSV), Pneumonia in beef calf herds despite vaccination. Acta vet. Scand. 2001, 42, 113-121.

Lathrop SL, Wittum TE, Brock KV, Loerch SC, Perino LJ, Bingham HR, McCollum FT \& Saif LJ: Association between infection of respiratory tract attributable to bovine coronavirus and health and growth performance of cattle in feedlots. Am. J. Vet. Res. 2000, 61, 1062-1066.

Lauerman LH: Mycoplasmas of the bovine respiratory tract. In: Whitford $H W$, Rosenbusch $R F$, Lauerman LH (eds): Mycoplasmosis in animals. Iowa State University Press, Ames, 1994, 50-56.

Lekeaux P: Bovine respiratory disease complex: A European perspective. Bov. Pract. 1995, 29, 7175.

Mattson DE: Adenoviruses, In: Castro $A E$ \& Heuschele WP, (eds). Veterinary diagnostic virology, a practitioner's guide. Mosby, St. Louis, 1992, 70-72.

Moreno-Lopez J: Acute respiratory disease in cattle. In: Dinter Z \& Morein B (eds). Virus infections in ruminants, Elsevier publishers. B.V., Amsterdam, 1990, 551-554.

Mosier DA: Bacterial pneumonia. Vet Clin. North Am. Food An. Pract. 1997, 13, 483-493.

Niskanen M, Salmela P, Hirvelä-Koski V \& Kuronen $H$ : Haemophilus somnus -bakteeri vasikan keuhkotulehdusten aiheuttajana Suomessa. Haemophilus somnus as a cause of calf pneumonia in Finland. Suom. Eläinlääkäril. 1999, 11, 578-580. (In Finnish).

Norström M, Skjerve E \& Jarp J: Risk factors for epidemic respiratory disease in Norwegian cattle herds. Prev. Vet. Med. 2000, 44, 87-96.
Obando C, Baule C, Pedrique C, Veracierta C, Belák $S$, Merza M \& Moreno-Lopez J: Serological and molecular diagnosis of bovine viral infections in dairy calves with respiratory disease in Venezuela. Acta. vet. Scand. 1999, 40, 243-262.

Potgier LND: Bovine respiratory tract disease caused by bovine viral diarrhea virus. Vet. Clin. North Am. Food An. Pract. 1997, 13, 471-481.

Rikula U: Naudan RS- ja koronavirusvasta-aineiden esiintyminen Suomen lypsykarjoissa kevättalvella 2000, Prevalence of antibodies against bovine respiratory syncytial virus and coronavirus in Finnish dairy herds in early spring 2000, Suom. Eläinlääkäril. 2000, 12, 712-715. (In Finnish).

Roy JHB: Respiratory infections. In: Roy JHB: The Calf, Management of Health, Butterworths, London, 1990, 132-153.

Scholz H, Amtsberg U, Westermilies A, Binder A \& Kirchhoff $H$ : Untersuchungen zur Bronchopneumonie des Rindes, 1. Versuchsanstellung und mikrobieller Status von Nasen- und Tracheobronchialsekret. Investigations to bovine respiratory disease. 1. Experimental procedure and microbiological findings in nasal and tracheobronchial secretion. Tierärztl. Umschau 1987, 42, 272-280. (In German).

Sihvonen L \& Tuomi J: A seroepidemiological survey of adenovirus activity (types 1-3) at two Finnish calf-rearing farms. Acta. vet. Scand. 1978, 19, 192-203.

Storz J, Stine L, Liem A \& Anderson GA: Coronavirus isolation from nasal swab samples in cattle with signs of respiratory tract disease after shipping. J. Am. Vet. Med. Assoc. 1996, 208, 1452-1455.

Storz J, Lin X, Purdy CW, Chouljenko VN, Kousoulas $K G$, Enright FM, Gilmore WC, Briggs RE \& Loan $R W$ : Coronavirus and pasteurella infections in bovine shipping fever pneumonia and Evans' criteria for causation. J. Clin. Microbiol. 2000, 38, 3291-3298.

Tanskanen $R$ : Colonisation pattern of the respiratory tract of calves by Mycoplasma dispar. Acta vet. scand. 1984, 25, 577-592.

Tanskanen $R$ : Experimental and epidemiological studies on mycoplasma dispar infection in calves. Diss., Coll. Vet. Med. Helsinki 1987. 68p.

Tegtmeir C, Uttenthal A, Friis NF, Jensen NE \& Jensen HE: Pathological and microbiological studies on pneumonic lungs from Danish calves. J. Vet. Med. B. 1999, 46, 693-700.

Uttenthal A, Jensen NPB \& Blom JY: Viral aetiology 
of enzootic pneumonia in Dainish dairy herds: diagnostic tools and epidemiology. Vet. Rec. 1996, 139, 114-117.

Virtala A-MK, Mechor GD, Gröhn YT, Erb HN \& Dubovi EJ: Epidemiologic and pathologic characteristics of respiratory tract disease in dairy heifers during the first three months of life. J. Am. Vet. Med. Assoc. 1996, 208, 2035-2042.

Virtala A-MK, Gröhn YT, Mechor GD, Erb HN \& Dubovi EJ: Association of seroconversion with isolation of agents in transtracheal wash fluids collected From pneumonic calves less than three months of age. The Bov. Pract. 2000, 34, 77-80.

Walker RL: Bovine Mycoplasmosis: Current perspectives, proceedings of the 27th annual convention American association of bovine practitioners, 1995, 27, 3-7.

Welsh RD: Bacterial and mycoplasma species isolated from pneumonic bovine lungs. Agri Practice, 1993, 14, 3-16.

Wikse SE \& Baker JC: The bronchopneumonias. In: Smith BP (ed.) Large Animal Internal Medicinen, 2. ed. Mosby, St. Louis, 1996, 632-650.

\section{Sammanfattning \\ Förekomst av luftvägspatogener vid enzootisk pneu- moni i finska nötbesättningar.}

Studien genomfördes under åren 1998-1999 för att få grundkunskap om förekomsten av infektionsämnen associerade med kalvarnas luftvägsinfektioner i Finland. Alla 18 besättningarna hade problem med luftvägssjukdomar. I varje besättning utvaldes 5 sjuka kalvar för noggrann undersökning och tracheobronkiell sköljning. För serologiska undersökningar av virusantikroppar togs blodprov från 86 kalvar med 34 veckors mellanrum. Från samma besättningar togs dessutom 6-10 serumprov från nöt i olika åldersgrupper, sammanlagt 169 prov. Serumproverna analyserades för antikroppar mot parainfluensavirus typ 3 (PIV-3), bovint respiratoriskt syncytialt virus (BRSV), bovint coronavirus (BCV), bovint adenovirus typ 3 (BAV-3) och bovint adenovirus typ 7 (BAV7). En tredjedel av proverna analyserades dessutom på antikroppar mot bovint virusdiarrevirus (BVDV) med negativt resultat. De tracheobronkiella skjölproverna undersöktes på mykoplasmer och andra bakterier. Enligt serologiska resultat tycks PIV-3, BAV-7, BAV-3, BCV och BRSV förekomma allmänt hos besättningar med luftvägssjukdomar i Finland. Serokonversion konstaterades oftast mot BAV-7 och BAV3. I bakteriologiska undersökningar av sköljproven isolerades bara få patogener. De mest allmänna bakterieisolaten var Mycoplasma dispar och Pasteurella multocida tillsammans. Alla Pasteurella sp. isolat var känsliga för testade antibiotika. Mannheimia haemolytica och M. bovis kunde inte påvisas i något prov.

(Received June 7, 2004; accepted September 13, 2004).

Reprints may be obtained from: Heidi Härtel, LSO Foods Oy, Animal Health Service, Turuntie 4, 30100 Forssa, Finland. E-mail: heidi.hartel@1so.fi, tel: +358 3415 9307, fax +35834334363. 